\title{
ORIGEN ÁRABE DE «HAZA»
}

\author{
Dolores Oliver Pérez
}

Universidad de Valladolid

Quiero adelantar que este artículo, así como un trabajo complementario, que tengo el propósito de publicar, no me pertenece en su totalidad. Está parcialmente basado en notas de Jaime Oliver Asín halladas en una carpeta en cuya cubierta se lee: "Origen árabe de haza, contribución al estudio del vocabulario y de la toponimia hispano árabe», y la fecha: «año 1949».

El examen de los papeles contenidos en ella pone de manifiesto que J. Oliver tuvo intención de elaborar un artículo con el propósito de demostrar que el castellano haza procede del árabe FAHs y que dicho trabajo iba a constar de dos partes: en la primera trataría de rechazar la tesis, hoy admitida, de que haza deriva del latín FASCIA, para después dejar patente que no existen problemas en el plano fonético y semántico que impidan defender el paso de FAḤs a haza. En la segunda examinaría una serie de topónimos nacidos como resultado de FAHȘ, parte en la que se proponía incluir nombres de lugar estudiados o mencionados en artículos suyos (Vaciamadrid, Vaciabotas, Azagalla) y otros nuevos entre los que estaría el burgalés Haza.

Desconozco los motivos que le llevaron a no dar forma definitiva a dichos apuntes e incluso me he llegado a preguntar si en algún momento tuvo dudas sobre esa tesis que quería defender y de la que, me consta, habló a sus amigos. Lo único que puedo decir es que en su Glosario inédito, en las entradas referentes a FAḤs, no guardó ficha alguna relativa a haza, y que parte de los topónimos a los que alude en esos papeles aparecen en su Glosario como procedentes de otras raíces árabes. Mi opinión es que comenzó con mucha ilusión a reunir documentación que le permitiera apoyar el origen árabe de haza y a buscar topónimos derivados de FAHS que sirvieran para reafirmar su teoría y que, en un momento dado, decidió guardar las notas recogidas y consagrarse a otras investigaciones. Es posible que la determinación de olvidarse de 
haza fuera motivada por el deseo de dedicar el mayor tiempo posible a su Glosario, pero también pudo suceder que pensase debía madurar esa tesis y esperar a encontrar nuevas bases para su apoyo, opinión que fundamentamos en el hecho de que la carpeta sobre haza no se encontraba entre aquéllas que, según él, contenían material que yo debía publicar o utilizar.

El hecho de no contar con un texto que pueda ser editado sino con fichas y breves apuntes y el que no siempre esté de acuerdo con el contenido de estos últimos me ha movido a elaborar un artículo en mi nombre y no en el de J. Oliver Asín, y a informar mediante notas, e incluso en el texto, siempre que reproduzco conceptos o noticias que a él pertenecen 1 .

En resumen, la idea de que haza procede del árabe FAHS es de J. Oliver Asín, pero utilizo mis propios argumentos para su defensa. El examen de sus papeles me hizo creer que existía la posibilidad de sostener que haza derivaba de FAHS pero, de la misma forma, sentí que dicha tesis sólo resultaría convincente si se ampliaban las noticias recogidas, se sumaban nuevos razonamientos y, sobre todo, se buscaba un enfoque distinto. Consecuentemente, inicié una investigación y, basándome en los datos reunidos, proyecté la redacción de dos artículos consecutivos: en el primero, me centraría en el origen árabe de $h a z a$; en el siguiente, en los reflejos de FAḤs en la toponimia española.

\section{PRIMERA PARTE: EL LATÍN «FASCIA» EN LA LENGUA ESPAÑOLA}

\section{Antecedentes}

En el DRAE ${ }^{2}$ se registran los términos haza y faja como descendientes del latín FASCIA 'faja' y se indica que el primero (con su variante antigua $f a z a$ ) es un derivado directo de la voz latina, frente al segundo, que llega al castellano a través del aragonés faxa.

1 No remito a J. Oliver Asín cuando hablo de las definiciones que se registran en diccionarios y obras que siempre consulto ni al citar trabajos a los que él alude y de cuya lectura extraigo mis propias conclusiones. Únicamente menciono su nombre al hacer referencia a libros que no he manejado, al ofrecer datos que tomo de sus notas y cuando reproduzco apuntes redactados por él.

2 Véase Diccionario de la Lengua Española, editado por la Real Academia Española (citado DRAE), ediciones 1968, 1970 y 1984. 
La etimología que da la Academia para ambos vocablos y el carácter dialectal que atribuye al castellano faja responden al criterio que los romanistas nacionales y extranjeros vienen manteniendo sobre el origen de los mismos. Así vemos, por ejemplo, que R. Menéndez Pidál, al examinar los resultados del latín FASCIA, estudia comparativamente el catalán y aragonés faxa; leonés fexa, faxa; gallego-portugués faixa e italiano fascia frente al castellano haza / faza, con el propósito de destacar que el sonido /š/ (procedente del lat. ISCI ) se extiende por casi la totalidad de España y sólo en Castilla aparece un sonido fricativo registrado bajo las grafias ıccı, ıZı o 'çı ${ }^{3}$; que García de Diego aduce faja y haza como la prueba más elocuente de la evolución sScI $>/ \theta /$ en Castilla y /š/ en los demás dialectos ${ }^{4}$; que W. V. Wartburg, al ofrecer una extensa lista de derivados de FASCIA, intercala entre ellos haza ${ }^{5}$; que Kuhn, al estudiar la difusión del mencionado vocablo latino por una parte de la Romania no deja de aludir a $h a z a{ }^{6}$ y que Díez registra la etimología consabida, aunque trae el haza castellano a través del provenzal faissa 'franja de tierra' 7 .

La lectura de diccionarios etimológicos y de las obras de éstos y otros importantes lingüistas ${ }^{8}$ revela que, al haberse dado por supuesto que haza y faja tienen un origen común, nadie se ha preocupado de investigar cómo se fueron fraguando los diferentes sentidos, ni de tratar de conocer cuándo y por qué el FASCIA latino 'tira de tela' se convirtió en el haza castellano 'porción de tierra labrantía'. El hecho de que los romanistas centren todo su interés en el plano fonético y se limiten, por lo general, a enumerar formas gráficas sin señalar significados ni fechas de documentación, hace que resulte muy difícil percibir en qué mo-

3 Menéndez Pidal, R., Orígenes del español, Madrid, 1956, \& 57. 1-3 (pp. 307-308).

4 García de Diego, V., "Evolución de algunos grupos con 's'", en Homenaje a R. Menéndez Pidal, 1925, t. II, p. 11, y Manual de dialectología española, Madrid, 1946, pp. 36, 62, 160, 185, 212, 256, 281, 309, según nota de J. Oliver Asín (= s.n. Oliver Asín).

5 Von Wartburg, W., Französisches etymologisches Worterbuch (cit. FEW), 1934, s.v. fascia, s.n. Oliver Asín. Véase también su Dictionnaire Etymologique de la Langue Française, París, 1975, s.v. fasce.

6 Kuhn, A., «Der lateinische Wortschatz zwischen Garonne und Ebro", en Zeits. für, rom. Phil., 1937, p. 351, b, s.n. Oliver Asín.

7 Díez, F., Etymologisches Wörterbuch der romanische Sprache, Hildesheim, Olms, 1985, p. 458, s.v. haza.

8 Véase también Sanchís Guarner, M., "El mozárabe peninsular», en Enciclopedia Lingüística Hispánica, I, p. 317, \& 55. La existencia de un español haza equivalente al it. fascia y al franco faisse se señala también en el Thesaurus Linguae Latinae (cit. ThLL), s.v. fascia. 
mento hablan de uno $\mathrm{u}$ otro derivado $\mathrm{y}$, consecuentemente, preparar una exposición que dé a conocer lo que hasta ahora se ha dicho sobre faja y haza. El deseo de informar de la manera más clara posible nos ha llevado a reunir y ordenar las noticias que sobre ellos hemos podido recoger y a presentarlas bajo sucesivos epígrafes.

\subsection{El latín FASCIA}

En los diccionarios comunes de latín-español, bajo la entrada de FASCIA encontramos "venda, vendaje, cinta, banda; faja [de la mujer o del niño] y diadema, corona real" " ; en los etimológicos se señala, además, que dicha voz procede del latín FASCIS 'haz, manojo' 10.

Según los romanistas el latín tardío cuenta con un FASCIA 'medida agraria' que se aplicó a fajas estrechas de terreno, sentido que no se explica ni documenta de manera clara. Así vemos, por ejemplo, que en Du Cange se define FASCIA como 'modus agri', se aportan tres citas (siglos XII-XIV), en las que no creemos captar dicho significado, y se remite a faicia ${ }^{11}$, siendo bajo esta segunda voz donde se enumeran las diversas variantes (faissa, faissia, faisa, faxia, fayssia, faxa y foxa) y se efectúan observaciones sobre su contenido sémico que resultan, por cierto, bastante confusas ${ }^{12}$. Los textos que se aducen están en su gran mayoría tomados de cartularios y tabularios franceses de los siglos XII-XIV. He aquí algunos ${ }^{13}$ :

Concedimus... quidquid juris habemus in Fascia quae est inter nemus et aquam (Tabulario B. M. de Rupe forti anno 1194, en DC, s.v. fascia).

\footnotetext{
9 Véase como ejemplo el Diccionario ilustrado latino-español, español-latino Vox, con prólogo de García de Diego, V., Madrid, 1980, cuyo texto reproducimos aquí. En la parte española se da para faja 'fascia, toenia, cingulum y vitta'.

10 Ernout, A., et Meillet, A., Dictionnaire étymologique de la langue latine, París, 1979, p. 218.

11 Du Cange, Glossarium mediae et infimae latinitatis, 5 vols., Graz, Akademische Druck, 1954, vol. III, p. 418 s.v. fascia.

12 Ibid., p. 396, s. v. faicia. He aquí un ejemplo: en la entrada de esta segunda voz, se describe la variante fayssia como: «Modus agri, forte ab ejus forma sic dictus, quod sit ad instar ligulae seu fasciae, vel in longum protendatur", definición en la que "modus" parece designar 'forma' y no 'medida'; después, en el párrafo correspondiente a faxa, se dice "con el mismo significado, según parece», pero a continuación, tras el texto que lo documenta (cfr. supra) se añade: «Ubi Faxa, videtur esse facies, nos diceremos, sauf une face de terre, qui est devant la port, y se indica que el español faxa designa 'lengua de tierra'.

13 En las citas utilizo cursiva para destacar los vocablos en estudio.
} 
Recognoscimus vobis... totum honoren infra scriptum, videlicet quandam Faiciam quae vocatur Faicia dels Codalizes, quae est in fischa D. Episcopi Uticensis, in parrochia S. Laurentes... et alia Faiciam quae est in eadem fischa (Tabul. Eccl. Uticensis, año 1241, en ibid., s.v. facia).

Crescanos de Biens Judaeus civis Massil.: vendidit Johanni de Vapingo civi Massil. una Faiciam orti. (Instrum. anni 1332, ex Archivo S. Victoris Massil, en ibid.)

Item ab haeredibus Guillelmi Boc ignobili, qui ab ignobili acquisiverat Faissiam juxta terram mansi de Boisso pretio 30 libr. (Charta in R. C. exarata ann. 1306, ex. Tabularii Regii en ibid. s.v. faissar/faissia.)

Item apud Ursellum tres Faisas, et tria nemora (Charta Alexandri PP. ann. 1160, in Tabulario Humolairensi, en ibid., s.v. faisa).

Praescriptam autem Fayssiam vineae, superius in dotem et dotis nomine Alaetae constitutam et assignatam, cum omnibus juribus et pertenentiis suis promisit (Mss. ex Cod. reg. 7657 (siglos XIv-Xv), en ibid., s.v. fayssia).

Dimitto tibi Raymundo... tertiam partem de manso Guigo, quod est in villa de Vallesias praeter una Faxam de terra, quae est ante portam Jo. Revelli (Vetus Ch. ann. 1126 P. Abb. Axianensi, en ibid., s.v. faxa).

\section{2. Étimos y significados atribuidos a «faja»}

Covarrubias ${ }^{14}$ y Autoridades ${ }^{15}$, en sus artículos de faxa, traen dicha voz del latín FASCIA y la describen mediante palabras prácticamente idénticas. He aquí la definición de Covarrubias:

Una cinta ancha la cual sirve para muchos ministerios. Con ella atan los niños después de embueltos en las mantillas (...). Faxa, cerca de las mugeres, es una faldilla, a rayz de la camisa, y ésta aprietan con una angosta que llaman faxero y también faxa. Las guarniciones que echan a los vestidos llaman faxas. Los antiguos [es decir, los árabes] usavan en lugar de calças unas faxas que se rodeavan a las piernas, desde el tobillo hasta la rodilla; y éstas se llamavan fascias crurales. Oy día usan dellas algunos labradores, gentes del campo y pastores...

En el DraE se indica que el castellano faja procede del antiguo aragonés faxa y éste del latín FASCIA y se dan ocho definiciones, la primera de las cuales es "tira de tela o de tejido de punto, de algodón, lana o

14 Covarrubias, S. de, Tesoro de la Lengua Castellana o Española (Madrid, 1612), Madrid, Turner, 1979.

15 Real Academia Española, Diccionario de Autoridades (1732), ed. facsímil, 3 vols., Madrid, Gredos, 1969. 
seda con que se rodea el cuerpo por la cintura, dándole varias vueltas». En lo que respecta a las restantes, unas asumen valores metafóricos, otras son reveladoras de que faja vino a designar cualquier tipo de banda o lista "mucho más larga que ancha", sin indicar que esta voz se utilizara en el sentido de 'faja de tierra'.

Corominas ${ }^{16}$ trae faja del latín FAScIA 'venda', 'banda', 'sostén de pecho', derivado de FASCIS 'haz', y afirma que los testimonios con dicho significado aparecen en fecha tardía, no localizándose ninguno en el Cid, Berceo, Apolonio, Calila e Dimna, Conde Lucanor, J. Ruiz, glosarios de 1400 y demás textos medievales. El mismo autor señala como primera documentación el Vocabulario de Alonso de Palencia (a. 1490) ${ }^{17}$ e indica que «fašša aparece ya en el XIII como voz mozárabe».

La consulta de otros diccionarios permite añadir los siguientes datos: Dozy ${ }^{18}$ en la entrada correspondiente a la raíz F šs š, que designa 'deshinchar, combatir las flatuosidades', apunta que el árabe fašša 'faja, banda', deriva del español faxa, faja; el Vocabulista trae, como equivalentes del latín FASCIA los nombres árabes fǎša, fišaš y fașqiya ${ }^{19} ; \mathrm{P}$. de Alcalá traduce "faxa o faysa", "faxa de pecho" y "faxa de mujer" por el árabe fáyŷa (transcrito fayja) ${ }^{20}$; Simonet 21 informa que la variante fazquía se usó en castellano antiguo y que la grafía fasquía se documenta en rabínico así como en antiguo portugués y castellano; y, finalmente, en el Diccionario de Beaussier, que registra el árabe vulgar africano, encontramos un fašša 'borde, orilla, orla de la tela' ${ }^{22}$, que podría identificarse con una de las definiciones que trae Covarrubias de faja, la de "guarniciones que echan a los vestidos».

16 Corominas, J., y Pascual J., Diccionario crítico etimológico castellano e hispánico (cit. DCEC), 5 vols., Madrid, Gredos 1980-81, s.v. faja.

17 Véase Universal Vocabulario de Alonso de Palencia, ed. Hill, J. M., Madrid, 1957, p. 77, s.v. faxa, donde leemos: «faxa es fascia con que cubrimos el pecho y reuolvemos en torno al cuerpo".

18 Dozy, R., Supplément aux dictionnaires arabes, ed. 1967, II, p. 268.

19 Vocabulista in arábico..., ed. Schiaparelli, Firenze, 1871, p. 384. Ed. Corriente, F., El léxico árabe andalusí, Madrid, 1968, p. 230.

20 Alcalá, P. de, Arte para ligeramente saber la lengua arauiga, ed. P. de Lagarde, Gottingen, 1883, p. 251, 21-23.

${ }_{21}$ Simonet, F. J., Glosario de voces ibéricas y latinas usadas entre mozárabes, reimpr. Amsterdam, 1967, p. 199-200, s. v. façquíya.

22 Beaussier, M., Dictionnaire pratique arabe-français, 2. ${ }^{a}$ ed. par Ben Cheneb, M. Argel, 1931, p. 506, s.v. fašša. Simonet, F. J., en ob. y art. cit., también remite para este fašša a Quatremère. 


\section{3. Étimos y significados atribuidos a «haza»}

En los Diccionarios de Covarrubias y Autoridades no se da etimología de haza, aunque se sugiere que dicha voz procede del latín FAscis 'haz', ya que en el primero se insertan las explicaciones sobre haza en el artículo de hazina 'lugar donde se juntan y recogen las haces' y en ambos se ofrecen las siguientes definiciones:

«Haza, propiamente se llama el campo donde se ha segado el trigo y está sembrado todo de los hazes que dexan hechos los segadores, y se los tienen allí a secar algún día para llevarlos después todos juntos a la era con las carretas, como es ordinario. Haza se dice también en la tierra sembrada" (Covarrubias).

«Haza, propiamente se llama assi el campo donde se ha segado trigo u otra semilla, y que está ocupado de los haces y gabillas que han hecho los segadores; y también se llama assí una cierta porción de tierra, aunque no esté sembrada. Latín Seges, Ager...» (Autoridades).

En el DraE se registra haza como descendiente directo de FASCIA y se dan dos acepciones: 'porción de tierra labrantía o de sembradura' y ant. fig. 'montón o rimero', y se indica que la expresión mondar la haza es «desembarazar un sitio o paraje, a semejanza del labrador cuando levanta la mies».

Corominas habla del término haza en el artículo de haz 'porción atada de leña u otros vegetales', y no atribuye a sus dos significados idéntico origen. Este autor sostiene que en su sentido de 'porción de tierra labrantía' deriva del latín FASCIA 'faja' y ues frecuente en escrituras de los siglos X-XII, con las variantes gráficas fasca y fassa y la dialectal aragonesa faxa", mientras que la acepción anticuada de 'montón o rimero' procede "del romance haz y se halla en Cervantes», en una cita donde leemos: «mondaron luego la haza los ladrones» ${ }^{23}$. Asimismo advierte que la grafía haça se documenta por primera vez en el Arcipreste de Hita.

La lectura de otros diccionarios etimológicos da a conocer que, si bien parte de los lingüistas reproduce la tesis de la Academia, son bastantes los que optan por destacar un significado distinto. García de

23 Hemos de destacar que Corominas remite a una nota donde, tras reproducir el texto tomado de Coloquio de los Perros (en "Clásicos castellanos», II, p. 276) añade: «quizá no exista tal acepción pues es convincente la explicación de mondar el haza por 'limpiar el campo'...” 
Diego ${ }^{24}$, en la entrada de haza, remite al latín FASCIA, donde se limita a indicar que el castellano haza es 'faja de tierra'. Meyer-Lübke prefiere seguir a Covarrubias y dar para haza la definición de 'campo de gavillas' ${ }^{25}$, definición que también recoge Díez ${ }^{26}$. W. V. Wartburg ${ }^{27}$ dice que haza es "campo, propiamente, franja de tierra". En los diccionarios gallegos (bajo la forma $f a z a)^{28}$ y en Requejo (1717) encontramos la acepción de 'heredad' o 'heredad sembrada'; en Henríquez (1679) la de 'hacienda de campo' 29.

En lo que respecta a los arabistas no todos aceptan la teoría oficial. Federico Corriente relaciona haza con el árabe hișsa 'porción, parte, cuota' y cree ver en vuestro vocablo el sentido de "share" ${ }^{30}$, al igual que José María Fórneas, quien añade que en el siglo xvi haza se utilizó en Granada como equivalente a suerte y pedazo ${ }^{31}$.

Finalmente señalaremos que Aldrete y Cuervo defendieron la creación de haza a partir del árabe fahs, tesis de la que hablaremos más adelante y que es la que pretendemos apoyar aquí, siguiendo en dicho caso la opinión de Jaime Oliver Asín.

\subsection{Derivados del latín FASCIA}

Bajo este epígrafe reunimos datos que ofrecen los lingüistas cuando hablan en términos generales de los derivados de FAscia y presentan a haza y faja como variantes gráficas de una misma voz y no como dos vocablos distintos, lo que nos ha impedido utilizar sus informaciones para completar el contenido de los apartados anteriores.

24 García de Diego, V., Diccionario etimológico español e hispánico, Madrid: EspasaCalpe, 1985, pp. 221 y 672.

${ }_{25}$ Meyer-Lubke, W., Romanisches Etymologisches Wörterbuch, Heidelberg, 1968, s.v. facies la define como "mit Garben bedecktes Feld».

${ }^{26}$ Díez en ob. cit., s.v. haza contempla la grafía antigua faza y da dos acepciones: 'campo de gabillas' y 'tierra labrantía'.

27 Véase, Dict. Etymol, s.v. fasce: "champ, prop. bande de terre».

28 Cuveiro Piñol, J., Diccionario gallego, Barcelona, 1876.

29 Para la de Requejo véase Gili Gaya, S., Tesoro lexicográfico (1492-1726), Madrid, CSIC, 1947, s.v. aza. La de Henríquez la tomamos de una nota de J. Oliver Asín cuya fuente no hemos conseguido localizar.

30 Corriente, F., A grammatical sketch of the Spanish Arabic dialect bundle, Madrid, 1977, p. $27: 1.2 .3$.

31 "¿Algunos posibles arabismos? Datos para un estudio futuro de 'Arre', 'Borrego' y 'Haza'», en Actas de las Jornadas de Cultura Arabe e Islámica (1978), Madrid, 1981, pp. 115-124; p. 123. 
a) El latín FASCIA en el sentido primitivo y general de 'banda', especialmente aquélla que se arrolla al cuerpo de una persona, está representado en todo el territorio románico por vocablos directamente derivados de aquél, excepto en Castilla, donde faja ha de considerarse préstamo del aragonés faixa.

b) El mismo vocablo latino, en la acepción particular de 'banda de terreno', se registra ya en inscripciones de la Galia ${ }^{32}$ y perdura en Francia, Norte de Italia, Cataluña, Portugal y, por último, en Castilla donde haza aparece como perfecto derivado, conforme a la normal evolución fonética del castellano. Algunas voces de la Romania que se dicen hermanas de la palabra haza son las siguientes ${ }^{33}$ :

Faša, en Bordiguera, y fassa, en Monferrato (Italia) 'faja de terreno'; faisse, en el antiguo dialecto de la Champagne 'bande de terre, terre de forme allongée'; faissa, en el antiguo provenzal, y feiš, en Bessans 'bande étroite de terre entre les rochers'; faisses, en el Delfinado 'bandes étroites du terrain entre deux escarpements'; Las Faissas, en Barcillonnet (Hautes Alpes) 'bandes étroites recouvertes de végétation au-dessus de certains bancs de roche calcaire, dans un escarpement'; faisso, en Alpes Marítimos 'bande de terre soutenue par un mur'; fayssa, en Clermont 'partie d'un coteau compris entre deux murs de soutènement' ${ }^{44}$; faša, en los valles de Ansó y Hecho 'campo alargado 35; faja, en la Litera 'almanta', 'trozo de tierra muy largo y estrecho' 36; feixa, en Cataluña 'llenca de terra de conreu, bancal ${ }^{37}$ ' y faixa, en Portugal 'extensão de terra pouco larga, tira de terra, courela' o 'porção de terra cultivavel coprida e estreita' 38 .

32 Pirson, La langue des inscriptions de la Gaule, París, 1901, p. 255, s.n. J. Oliver. En ThLL, p. 298, para documentar el sentido de "mensura agri», se alude a Pirson y se remite a C. I. L., XII, 6032 a. En dicho volumen, que corresponde a Inscriptiones Galliae Narbolensis Latinae, sólo hallamos un testimonio (6032 a): "fines fasciae fundi pacatiani".

33 Copiamos aquí una nota donde Oliver Asín recoge vocablos a los que se les asigna el sentido de 'faja de tierra'. Esta lista puede ampliarse de manera considerable si se incluyen todos los que menciona W. von Wartburg, en FEW, Band II (ed. 1971), s.v. fascia, pp. 425-426.

${ }_{34}$ W. von Wartburg, FEW, s.v. fascia, s.n. de Oliver Asín...

35 A. Kuhn, «Der lateinische Wortschatz...», p. 351, s.n. Oliver Asín.

36 Coll, Colección de voces usadas en la Litera, s.n. Oliver Asín.

37 Diccionari de la llengua catalana, ed. Salvat, s. n. Oliver Asín.

38 Caldas Aulete, Dicionario da lingua portuguesa, Lisboa, 1925, s.n. Oliver Asín. 


\subsection{Información complementaria}

El examen directo de fuentes documentales así como la lectura de diccionarios bilingües nos autoriza a sumar dos últimas observaciones:

a) Un estudio diacrónico enfocado a conocer las grafías y significados que se registran en las diferentes épocas permite ofrecer la siguiente información:

1. ${ }^{\circ} \quad$ El sentido de 'tierra', 'campo' es el que aparece en época más temprana (a. 800) ${ }^{39}$ y el que se repite con más asiduidad. Podemos decir que dicho significado ha de considerarse propio de la forma gráfica $f a z a^{40}$ o de sus equivalentes faca, facca, faça ${ }^{41}$, grafías todas ellas que, a partir del siglo xIv, pasarán en Castilla a convertirse en haza / haça mientras que en zonas como Asturias o Galicia se conservará el antiguo faza. Frente a un alto número de testimonios de las grafías mencionadas, que pertenecen a los siglos X-XIII, sólo tenemos noticia por Menéndez Pidal de dos ejemplos de fasca (años 1059-1081) en un documento aragonés ${ }^{42}$.

2. $\quad$ De la acepción de «faja de tierra" únicamente conocemos dos posibles testimonios que se registran en un acta leonesa (a. 1104) y en otra aragonesa (1140), donde aparecen respectivamente las expresiones "fexa de terra" y "faxa de terra" ${ }^{43}$. Según el Diccionario etimológico de Godefroy, el sentido de 'bande de terre' se documenta por primera vez en Francia en 1278, en dos textos del Cartulario del obispado de Laon, donde se habla de "trois faisses" y de "plusieurs faisses", y vuelve a recogerse en 1431 en otro en el que se mencionan ciertas "faisses de terre» ${ }^{44}$.

3. ${ }^{\circ}$ Del sentido de 'medida agraria' contamos también con dos

39 Para la documentación de esta fecha véase p. 138, donde reproducimos un texto del Cartulario de San Millán de la Cogolla.

40 La documentación de esta grafía y significado se hará más adelante en nuestro estudio sobre haza.

41 Hemos de tener en cuenta que las grafías i $\mathrm{c}$, , $>\mathrm{cc}$, corresponden a lo que en época posterior tomará la forma de ıçı y que los sonidos que estas consonantes representan a menudo se confunden con los correspondientes a las grafías izı y 'ss

42 Menéndez Pidal, R., Orígenes, and 57.1, p. 307, trae la siguiente cita: «dua fascas et una terra..., una fasca» (Cartulario de Sos). No podemos incluir aquí «illa casa dEissauir, et duas fassas in Campo Macro et illa fassa en Raspera (San Juan de la Peña, a 1101) que se mencionan en ibid, al estar ante vocablos cuyo sonido era similar a faza.

43 Ibid.

44 Godefroy, F., Dictionnaire de l'ancienne langue française du IX au XV siècle, Genève-Paris, 10 vols. (1880-1002), III, p. 716, s.v. faisse. 
únicos testimonios de faza localizados en un documento toledano escrito en castellano, del año 1234, en el que se citan «las viñas de Torres, VII Fazas et el sesmo" y "las viñas de Alcardeth, duas fazas y media quarta" ${ }^{45}$. No creemos que dicho valor deba atribuirse a un faxa del año 1147 registrado en un Cartulario de Huesca: ("comparauerunt... VIII terras et II faxas de uineis de domno Enneco Lopiz») ${ }^{46}$ que Menéndez Pidal presenta como prueba de que estamos ante un derivado del latín FASCIA 'medida agraria'; y es nuestra opinión que dicho valor no se capta, al menos con claridad, en las citas que trae Du Cange.

4. ${ }^{\circ} \quad$ El significado de fecha más tardía es, repetimos, el de 'faja de tela', que no se documenta hasta finales del siglo $\mathrm{XV}^{47}$ y que corresponde a las grafías faysa, faxa y fasca, habiendo de señalar que no hemos conseguido encontrar testimonio alguno de faza 'banda de tela'.

b) La lectura de diccionarios bilingües da a conocer que las actuales lenguas romances no cuentan con voces que, asemejándose fonéticamente a haza o faja, encierren los contenidos sémicos que señala la Academia como propios de nuestro haza. Así vemos, por ejemplo, que en los diccionarios franceses se da como equivalentes del español haza la expresión 'pièce de terre labourable' ${ }^{48}$, en los italianos 'campo', 'seminato' ${ }^{49} \mathrm{y}$ en los portugueses 'terra de semeadura' 50.

Algo muy diferente sucede con faja 'banda' o 'cinta' que, como derivado de FASCIA, se conserva en francés (fasce), en italiano (fascia) y en portugués (faixa), aunque con menor vitalidad que en español.

\section{Primeras conclusiones y plan de este trabajo}

El estudio de las diferentes noticias que hasta ahora hemos podido reunir sobre el origen y contenido de haza y faja nos ha permitido ex-

\footnotetext{
45 Véase "Memorial de las aldeas de la Iglesia de Toledo", en González Palencia, A., Los mozárabes de Toledo en los siglos XII y XIII, Madrid, 1930, vol. preliminar, p. 166.

46 Menéndez Piḍal, R., Orígenes, p. 307.

47 Martín Alonso, en su Diccionario medieval español (Universidad Pontificia de Salamanca, 1986, 2 vols.), da como $1{ }^{\text {a }}$ doc: "vara y media de cebli carmesí para una faysa" (Baena, Cuentos, 1488-91).

48 Reyes, R., Diccionario francés español, Madrid, 1963.

49 Abruzi, L., Nuovo dizionario spagnolo-italiano, Turín, 1948. 1977.

so Ortega Cavero, D., Diccionario portugués-español, español-portugués, Barcelona,
} 
traer unas primeras conclusiones que serán las que abran la puerta por la que más tarde entremos para defender el origen árabe de haza.

\subsection{Observaciones sobre "faja»}

No hay duda de que en nuestro romance existió un faxa, fasca (derivado del latín FASCiA y origen del actual faja), que se ha venido usando en el sentido de 'faja de tela' y de manera esporádica en el de 'faja de terreno', lo mismo que ha sucedido con las voces hermanas que pertenecen a las diferentes lenguas románicas.

Es evidente también que las noticias que los lingüistas ofrecen sobre este término son a menudo confusas y que se hace necesario realizar nuevas investigaciones para responder a las muchas interrogantes que su estudio suscita y que no atañen directamente a su origen, del que nadie duda, sino a su contenido sémico.

Creemos que sólo cuando se reconstruya la historia de esa voz, labor que nosotros no nos proponemos realizar aquí, será posible encontrar explicación a preguntas que nos hemos hecho a lo largo de nuestro trabajo, como son las siguientes:

a) Cuál es la razón de que se documenten por primera vez en mozárabe y sea en español donde el derivado de FAScia, que designa 'faja', tenga una mayor vitalidad.

b) Cuándo y bajo qué grafías se registra en Castilla, y si la forma gráfica faja procede del aragonés, como se admite de manera unánime,

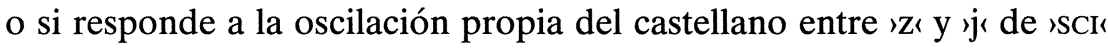
+ vocal ${ }^{51}$. En apoyo de esta última hipótesis diremos que resulta muy sintomático el que los lingüistas, para defender la conversión del isCi latino en 'zı castellana, repitan siempre los ejemplos de haza y azada cuando sabemos que existió la forma gráfica axada ${ }^{52}$, y que las citas a las que remiten para documentar el segundo pueden contener un faza de origen no latino. Asimismo, ha de considerarse extraño que el castellano no tenga representante directo de FASCIA cuando lo tiene el resto de las lenguas y que sea voz prestada la que tantos derivados ha dado, ya que del faja castellano vienen, según el DRAE, fajín, fajero, fajuela, fajón y refajo.

51 Véase Hanssen, F., Gramática histórica, \& 144, s.n. Oliver Asín.

52 Ibid., s.n. Oliver Asín. 
c) Una última pregunta que se hace preciso contestar es si la acepción de 'medida agraria' corresponde a este faja o al faza cuyo origen árabe defendemos; es decir, si se crea a partir del sentido de 'faja de tierra' o estamos ante un significado que nace de un faza 'campo' que ha sufrido una evolución semántica análoga a la de otros términos ára-

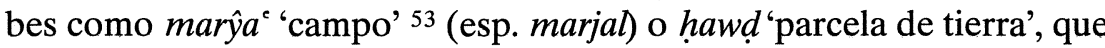
se convirtieron en nombres de medidas agrarias ${ }^{54}$.

En suma, para conocer la historia de faja, y para completar la de ha$z a$, que trataremos de reconstruir aquí, se hace preciso un estudio exhaustivo de fuentes, y hacerlo conscientes de que existe un árabe fahs 'campo, tierra'. Si nosotros hemos conseguido percibir cómo nace y evoluciona haza, gracias al análisis de "todos" los testimonios que de posibles derivados de fahs o fascia se registran en un número importante de documentos notariales de la primitiva Castilla, y del estudio paralelo del lenguaje utilizado en cada cartulario en particular, creemos que cuando se efectúe un examen similar de los correspondientes a zonas como Aragón y Cataluña podremos saber cuál es el origen de esos testimonios aislados de faxa y fasca que citan los lingüistas y el de los faixa, feixa que aparecen en diccionarios de dichas regiones, como equivalentes a haza, y de los que se ofrecen noticias muy confusas. Sólo entonces será posible descubrir si tales vocablos se han creado a partir de un FASCIA 'faja de tierra'; si son voces hermanas del haza 'campo, tierra labrantía' (en cuyo caso estaríamos ante grafías que son fruto de la pronunciación, en determinadas zonas, del /ș/ árabe como /š/), o incluso, si en su proceso generativo intervinieron los dos étimos, el latino y el árabe.

\subsection{Observaciones sobre «haza»}

Lo primero que llama la atención es que no existe unanimidad de criterios en lo que respecta al origen de haza, ni tampoco en lo que atañe a su contenido sémico, y que los filólogos encuentran muchas dificultades al tratar de explicar el nacimiento y desarrollo de este vocablo que, además, es voz exclusiva del español.

53 En el Vocabulista, p. 234, se traduce por el latín ager

54 Véase nuestro artículo "Contribución al estudio de la terminología agrícola...", Anaquel de Estudios Árabes, III (1992), pp. 202-205. 
a) Si nos centramos en el primer punto, vemos que, si bien todos los lingüistas coinciden al señalar que faja procede del latín FAscia, no sucede lo mismo con haza, quizá porque resulta muy difícil defender que una voz cuyo sentido originario es el de 'cinta o faja' dé en el siglo $\mathrm{x}$ un derivado de gran vitalidad que designa 'campo o tierra' $\mathrm{y}$ que haya que esperar al siglo $\mathrm{xv}$ para encontrar testimonios de lo que podemos considerar el significado primitivo. Lo lógico sería hallar en el siglo $\mathrm{x}$ un faja / faza 'tira de tela'; que poco después apareciera el mismo como 'tira de terreno'; y que a partir de ese momento fuéramos encontrando textos donde paulatinamente se captaran valores como 'tierra' o 'tierra labrantía'. No es extraño, por lo tanto, que algunos hayan desechado FASCIA para derivar el antiguo faza del latín FAscis o del castellano haz y que no falten quienes han vuelto su mirada hacia la lengua árabe para buscar en ella un étimo que resulte más adecuado.

b) En lo que respecta al plano fonético, el admitir que faza procede del latín FASCIA conlleva graves problemas, sobre todo, cuando se sabe que haza y faja fueron voces usadas por los mozárabes y que entre ellos el latín ısci ha dado siempre la prepalatal fricativa sorda /š/, lo mismo que ha sucedido en los dialectos de la Península orientales y occidentales, de evolución paralela. Si hasta el momento actual no se han esgrimido argumentos sólidos que expliquen la razón de ese haza de origen latino, la tesis tradicional pierde toda su consistencia en el momento en que se piensa en un FAH̦ como posible étimo y se examinan comparativamente los caracteres gráficos que emplearon los mozárabes como transliteración de los vocablos latinos y árabe. Por un lado, de todos es conocido que ha existido en mozárabe un faša, término hermano del aragonés faixa, o del castellano faja, en su significado de 'banda de tela', transcrito en las formas fašša, fašqyya, fayŷa ${ }^{55}$. Por otro, más tarde mostraremos que los mozárabes toledanos transcribieron el árabe FAḤs por faṣa, es decir, lo pronunciaron /faza/.

c) Si pasamos a analizar el contenido sémico de haza, pronto comprobamos que tampoco existe unanimidad y, lo que es más grave, sentimos que esta palabra ha sido mal definida y que el motivo no es otro que haber querido hacer palpable la etimología propuesta. A nuestro entender, sólo la primera definición que trae el DRAE bajo haza es

55 Véase nuestras notas 19-21. 
correcta ${ }^{56}$, y deben desecharse las de 'campo de gavillas' y de 'montón o rimero' por los motivos que exponemos a continuación.

En primer lugar creemos que haza nunca significó 'campo de gavillas'. Haza es palabra que se presta a confusiones por la homofonía con haces y por la preponderancia en ciertas regiones de las hazas de trigo; y ello nos hace suponer que si Cobarruvias, Autoridades, Meyer-Lübke y otros le atribuyeron tal acepción fue porque creyeron ver una relación semántica y etimológica entre ambas voces, y no se dieron cuenta de que haza no es un campo laborable sólo de trigo, pues puede haber "hazas de lino"; "hazas de viña»; "hazas de cardos comestibles»; "hazas de maíz» $\mathrm{O}$ "hazas de patatas y garbanzos» 57 .

En lo que atañe a la segunda acepción del DrAE, la de 'montón o rimero', queremos advertir que no se registra en los diccionarios antiguos ${ }^{58} \mathrm{ni}$ tampoco la hemos conseguido descubrir en ninguno de los muchos pasajes donde hemos visto empleada esta palabra.

La falta de antecedentes lleva a sospechar que la definición es incorrecta, y que estamos ante la errata de un editor que ha utilizado hazas como plural de $h a z$, error que ha quedado plasmado en los diccionarios cuando alguien se ha encontrado con un pasaje donde en lugar de haces [de trigo, por ejemplo] se leía hazas, y ha decidido consignar bajo la palabra haza el significado propio de haz 'porción o montón de cosas semejantes'. Dicha hipótesis surge al efectuar una investigación sobre uno de los testimonios al que se atribuye dicho significado y descubrir que la palabra hazas no aparecía en el texto originario. Nos referimos a un pasaje del historiador alicantino Carlos de Coloma en el que se habla de "un carro lleno de garbas de trigo" ${ }^{59}$, frase que en la edición de la Biblioteca de Autores Españoles ${ }^{60}$ se transforma en "un carro lleno de hazas de trigo", posiblemente porque al editor no le sonaba el murciano

56 Consideramos también adecuada la expresión "mondar el haza" del DRAE donde el sustantivo designa 'campo' (cfr. nota 23).

57 Las dos primeras se repiten en cartularios; para las restantes, véanse los textos de Henríquez de Jorquera y Pérez Galdós, pp. 144-145 de este artículo.

58 Esta definición se registra por primera vez en la edición del diccionario académico del año 1803.

59 Bellero, P. y J., Las Guerras de los Estados Bajos, Amberes, 1625, p. 424, s.n. de Oliver Asín, quien indica que la errata aparece por primera vez en la ed. de Barcelona de 1927 (Viuda E. Thomasa, fol. 239, en B. N. de Madrid, R. 14.176) y después en la de Amberes de 1635 (p. 472).

60 Véase t. XXVIII, 1853, p. 150. El texto dice literalmente: «Mostróles [Hernán Tello] un carro lleno de hazas de trigo que se llevaba, y advirtióles que debajo de las hazas más altas iban bien cubiertos gruesos tablones.» 
garbas 'gavillas' y decidió sustituir esta palabra por haces pero dándole la forma de un plural inexistente, hazas.

En suma, si admitimos que sólo es correcta la primera definición del DRAE y tomamos como base los datos reunidos, podemos formular la siguiente teoría: en castellano ha surgido y arraigado un vocablo faza, haza 'campo laborable' que no procede del latín, como siempre se ha creído, y que no tiene parentesco con las voces derivadas de FASCIA que, por designar únicamente franja de tierra estrecha y alargada, nunca han podido dar nacimiento a nombres de lugar como Haza Redonda ${ }^{61}$, topónimo que en seguida relacionamos con el Campo Redondo, frecuente en la nomenclatura geográfica.

Dado que el faza, haza 'tierra labrantía' puede aplicarse a todo terreno, cualquiera que sea la forma de su perímetro, y no es voz hermana de los derivados románicos de FASCIA, que ofrecen un sentido panrománico uniforme -el de 'tira estrecha y alargada', ya sea de tejido o de tierra- se hace preciso encontrar para el vocablo castellano un nuevo étimo. El conocimiento de que haza es una palabra particularísima del español y la búsqueda de la razón de este su aislamiento dentro del mundo románico lleva en seguida a pensar en un posible origen árabe. Es entonces, al fijar la mirada en la lengua de ese pueblo que convivió con los hispanos durante ocho siglos, cuando comprendemos que nuestro haza pudo fácilmente haber nacido del árabe FAHS en su amplio sentido de 'campo' y en el particular de 'campo que se labra'.

Consecuentemente, y a pesar de que la cuestión del origen de haza se da como definitivamente resuelta, nosotros vamos a ofrecer aquí una nueva teoría, en la creencia de que la historia verdadera de esta palabra está por descubrir.

Para defender nuestra tesis comenzaremos por destacar, documentar y completar la única acepción que creemos exacta, o sea, la primera que se registra en el DRAE; después explicaremos la perfecta correspondencia semántica entre haza y el árabe FAHṢ, y en último lugar, diremos algo sobre los antecedentes de nuestra etimología.

61 Topónimo de Benamargosa, Málaga, según el Dic. Corográfico. 
SEGUNDA PARTE: ORIGEN ARABE DE «HAZA»

\section{Significados de Haza: Autoridades}

Una vez que acabamos de desechar como erróneas las acepciones de 'campo de gavillas' y 'montón o rimero' trataremos de reconstruir la historia de esa primera definición que trae el DRAE, la de 'porción de tierra labrantía', y lo haremos conscientes de las relaciones de conjunción que se dan en nuestra lengua entre dicho significado y los que se atribuyen a campo y tierra, es decir, se tendrá presente que la Academia da para campo como segunda acepción 'tierra laborable' y para tierra, en su sexta 'terreno dedicado a cultivo o propio para ello'.

\section{1. 'campo', 'tierra', 'porción de tierra labrantía'}

Las acepciones aquí señaladas son las únicas que se pueden deducir de los primitivos textos romances, textos donde la palabra la encontramos empleada, alternando con sus sinónimos campo y tierra, y en sus formas arcaicas (faza, faca, facca, faça), como es natural.

Así vemos, por ejemplo, que ése es el significado de los tres testimonios del Cartulario de Valpuesta ${ }^{62}$, donde se registra el que figura en las papeletas de la Academia como de fecha más antigua ${ }^{63}$. En las dos primeras citas se percibe el sentido etimológico de 'campo', al aplicarse nuestro vocablo a tierras donde se cultivan árboles frutales y no cereales y al utilizarse, en la segunda, como claro sinónimo del latín agro y te$r r a$. En la tercera se capta otra de las acepciones del étimo, la de 'campo que pertenece a una población', ya que en dicho Cartulario cuando se menciona la propiedad no de una persona sino de un pueblo se usan los términos territorio o agro.

a. 950: «Uendimus illa faza quod habemus de nostro parente (...), cum quatour mazanos et uno perare et duodecim pumares, et suo fraxino in limite iusta mazanare de Maure" (C. de Valpuesta, doc. XXIV, p. $330)$.

${ }^{62}$ Barrau-Dihigo, L., "Chartes de l'église de Valpuesta du IX siècle», Revue Hispanique, VII, 1900, pp. 271-389.

${ }^{63}$ Véase J. M. ${ }^{a}$ Fórneas, art. cit., p. 121. 
a. 1050: «Si me trado (...) una faca ${ }^{64}$ con VII mazanos, in loco que dicitur Illa Torca (...) et alio agro a fonte de Ralo cum Il mazanos (...) pro ipsos agros cum mazanos iudicio plusaraberit (...) tales terras cum mazanos duplatos in tale terminos (ibid. doc. LV, p. 366).

a. 1050: tradimus nostras terras et nostra kasas (...) id est VI terras qui sunt in terretorio de Mamolica. Est illa una terra in loco que dicitur Feripecos, iusta terra de Munnio Albares; est illa alia trans la faza de la Kalcata" 65 (ibid., doc. LVI, p. 367).

El estudio de los cincuenta y dos testimonios hallados en el Cartulario de la Iglesia de Santa María del Puerto (Santoña) ${ }^{66}$, los cuales aparecen bajo la forma faza, a excepción de los cinco más antiguos (fac$c a)^{67}$, viene a corroborar la tesis de que en un principio haza se identificó con campo o tierra, a la vez que nos permite descubrir ejemplos que, siendo claramente representativos de dicho sentido, han sido citados por Menéndez Pidal como prueba de que faza designó 'faja' 68.

Nos referimos a tres apariciones de la expresión faza de tierra que en esta obra se usa como equivalente a la de agro de tierra, y en las que, curiosamente, el primer término haza o campo es seguido de un elemento determinativo tierra que asume el sentido de 'tierra labrantía'. Son testimonios, por lo tanto, en los que faza de tierra designa 'campo de tierra labrantía o cultivable' y que nos ayudan a comprender cómo se pasó del sentido primitivo al que se registra en el DraE. En apoyo de nuestras palabras presentamos dos textos paralelos que tratan respectivamente de la "venta de un campo ("agro") en Arnoio" 69 y de la "donación de un campo ("faza") en Ansuera" ${ }^{70}$.

${ }^{64}$ En este cartulario no se registra la consonante 'çı, lo que significa que este faca debe pronunciarse al igual que $f a c ̧ a$. Para entender que faça se usa aquí como equivalente a agro o tierra se ha de tener en cuenta que el documento trata de la donación de "dos" tierras.

65 El nombre de este pueblo se registra en otros cartularios como Kalçata / Kalzata / Calzada. Véase supra nota 64.

66 Este cartulario ha sido publicado en el BRAH, núms. 73-76 y 80. Aquí será citado como C. Santoña más el número del boletín y página.

67 Cuatro de ellos (a. 1047 y 1085) presentan la forma facca. Uno del año 1085, que se registra con la grafía haças, pensamos que corresponde a un facas que ha sido corregido, ya que no existe ningún otro ejemplo de dicha grafía anterior al XIV.

68 Véase Orígenes, p. 308.

69 Véase también un segundo texto muy similar (BRAE, 75, p. 347) perteneciente a un documento sin fecha en el que se dice por dos veces que Martino y su mujer Eilo donan un agro de terra para después repetirse la frase ipso agro iam dicto al referirse al mismo. Para la expresión duos agros de terra, véase doc. del año 1139 en ibid., p. 330.

70 En este cartulario aparece un tercer testimonio de esta expresión en un docu- 
a. 972: Uindimus ad uos Anfonso agro de terra quod est in Uilla de Arnorio nominato loco fonte petrosa (...) vindimus nos Feles e Goina ipso agro. iam dicto (...). Nos Feles e Golna de ipso agro iam dicto iure non seruauit (...) quomodo pariet ipso agro de terra duplato con fruge... [C. Santoña, en BRAH, 73 (1918), doc. V, pp. 426-427].

a. 1085: Donamus vel concedimus pro remedio animarum nostrarum ad eclesie Sancta Marie (...) una facca de terra qui est iusta termino de regula de Sancti Sthephani de Ansuero (...) donamus uel trademus nos Pedro et Citti et (...) ista facca de terra ad ipsa ecclesia (...) Quod si aliquis homo contradixerit pro ipsa facca, comodo pariet ea dupplata vel tripplata [ibid., BRAH, 74 (1919), doc. XXXVII, p. 33].

Frente al anterior, el sentido específico 'de tierra labrantía' es el que creemos percibir en la expresión «la tierra de Nozeda con sue faza est de Sancta Maria" (en doc. del año 1210) ${ }^{71}$, que trae a nuestra mente locuciones como "el prado de Fouielo con su tierra» ${ }^{72}$, "otra faza (...) con su uina e con toda la tierra» ${ }^{73} \mathrm{o}$ "un pumar con sue terre fundus (...) cum fructus et laboris que ibi fuerint" ${ }^{74}$. Si aquéllas en que hablan de un prado, pomar o haza semejan ser indicativas de que la venta o donación incluye la tierra de labor que existe dentro de ese campo, pensamos que en la locución "la tierra con su faza", el segundo elemento se usa como equivalente a tierra en el sentido de 'sembradura', vocablo, el último, que nunca aparece en este Cartulario y que, sin embargo, se repite en documentos de otras regiones.

Interés especial tiene la lectura de un curioso y extenso documento del año 1210 (BRAE, 75, pp. 335-345), en el que se enumeran los campos, tierras, hazas, sernas, etc., que, según los hombres de diversas villas, pertenecen a cada iglesia en particular y que permiten captar los sentidos primitivos de haza y su uso como sinónimo de tierra y campo. He aquí algunos de los testimonios contenidos en dicho escrito:

La tierra de la Ilzera est de Sancta Maria [según las gentes de Anero] (BRAE, 75 (1919), p. 336.

mento de 1210 (en ibid., p. 340) donde leemos: «Una faza de tierra in Arcabrandi est de Sancti Juliani."

71 Ibid., en BRAE 75, p. 338. El mismo sentido es el que atribuimos a "[venden] la uega de la canaliza con sue faza», en Menéndez Pidal, Documentos Lingüísticos de España (cit. DL) Madrid, 1919, p. 49. 22-23.

72 Ibid., p. 49.13.

73 Ibid., p. 270. 70-71.

74 C. Santoña, en BRAE 74, p. 34. Véase también en ibid., pp. 19, 23, 25; y 73, p. 437, donde leemos: «un pumar con sue terra». 
La faza de la Ilzera est de Sancti Iulani [según las gentes de Isla] (p. 339). En el Pinero tres fazas enna de uso ermun ${ }^{75}$. In illa de medio la tercia, et enna otra tierra la tercia, et in illa de suso la octava est de Sancta Eulalia (p. 337).

Enna Varcena duas tierras sunt de Sancta Eulalia (p. 337).

En Nepral duas fazas sunt de Sancta Eulalia (ibid.).

En Telferrero una faza est de Sancta Eulaia (ibid.).

Enna Cabrera una faza est de Sancta Eulaia (ibid.).

Ennos quadros duas fazas sont de Sancta Eulalia (ibid.).

Enna Monnueca una faza est de Sancta Eulalia (ibid.).

En Uzeli una media tierra est de Sancti Ihoannis (p. 343).

Una tierra en Lotatín est de Santa María (p. 338).

Una faza en Campo redondo est de Santa María (ibid.).

Una faza en parte rio est de Santa María (p. 339).

Una faza in valle est de Sancti Iulani (ibid.).

Una faza en Fontanilla est de Santa María (340).

Una faza en Pradinan de Sancti Iulani (ibid.).

Una faza de Alzerit es de Sancti Cipriani (343).

Una faza que tien Gonsalo Roiz es de Santa María (344).

El campo de Santi Facundi con (...) est de Santa María (p. 338).

El ero de Queto est de Santa María (ibid.).

La faza de sobre Pando es de Pineda (ibid.).

La faza de orilla de Fano est de Sancti Iulani (339).

La faza de Tenebregosillo est de Sancti Iulani (ibid.).

El ero de los Breones est de Sancti Iulani (340).

La serna del Fazin est de Santa María (ibid.).

La faza de Pedroso est de Santa María (ibid.).

Hel ero del pozo es de Santa María (341).

La tierra de Nozal est de Santi Stephani (ibid.).

La faza de Salzedielo que es de Sacti Petri (ibid.).

La faza delant la casa de Ioan Garziaz... que es toda de S. M. (341).

Ante casa de donna Taresa una terra est de S. Ihoannis (343).

La media faza de Murandot es del solar de Fonte negra (340).

Dixeron que la faza de Balruegas que es del solar de Fresnedo (ibid.).

El medio ero d'Arredondo que es del solar de Sango e. d. S. M. (341).

La media tierra de Vales que es de... e del solar de la cuesta (ibid.).

Una tierra en Tegero es del solar de Gonzalvo Roiz (ibid.).

75 Hemos corregido el texto (uso por iuso) al constatar que en éste (cfr. p. 60) y en otros cartularios hermun designa 'comunal' y carece de sentido el señalar que pertenecen a Santa Eulalia tres fazas o tierras que se encuentran dentro del terreno "de abajo comunal". La causa del error resulta fácil de entender, ya que inmediatamente después el escribano va a precisar qué parte de cada una corresponde a Santa Eulalia y para ello se ve forzado a indicar paralelamente la situación de las tres tierras; la de abajo (iuso) la de en medio o la de arriba. 
La faza del cereso es del solar de Roi Salvadores (342).

La tierra de las cubas es del solar de Martín Vicentez (ibid.).

[Según los hombres de ARgonio a Sancta María pertenecen]: «Una tierra a la Garma, otra tierra a Pereda; la faza de Mazmedio; un felgero en Barchero; en Aregones otra tierra (...); Sobre el Argero otra tierra; otra tierra al Perugo; otra faza a Tegero, que son de aquel solar...» (341).

La lectura de este documento también nos ha permitido descubrir el uso de Faza como apellido (Pedro Pérez de Fazapuele) ${ }^{76}$ y, lo que es más importante, que el término que hoy se denomina Hazas de Cesto y el pueblo que lleva el mismo nombre eran, ya a principios del XIII, conocidos como Las Tierras de las Fazas o Las Fazas, expresiones que aquí emplean, respectivamente, los hombres de Meruelo y de Guemes 77 cuando señalan las posesiones que pertenecen a la Iglesia de Sancta Maria, y dicen literalmente ${ }^{78}$ :

Las Tierras de las Fazas est de Sancta Maria de Porto (p. 338).

A Las Fazas las dua tercias de la faza est de Sancta Maria (ibid.).

Concluimos el análisis del Cartulario de Santoña con dos testimonios del siglo XI cuyo principal valor reside en su grafía. En el primer texto se citan los términos pertenecientes al monasterio de Sancta Cruce; en el segundo, aparece un Haças que ha tenido que introducir un copista en fecha tardía, posiblemente, porque no entendía el Facas que se registraba en el original o quizá, también, porque lo asoció con un topónimo que en su tiempo era conocido como Haças de Felguera ${ }^{79}$.

76 Un nuevo topónimo parece deducirse del nombre de este personaje que en dicho documento se dice vive en Castello (p. 340) y que, no hay duda, procede de un pueblo llamado Fazapuele, nombre que podría muy bien derivar de un Faḥ Abū 'Alà que, siguiendo una evolución normal, daría primero Faz-abu-Ale, y después Fazapuele. Sobre el nombre Ale, muy repetido, véase J. M. ${ }^{a}$ Mínguez, índice de Colección diplomática del Monasterio de Sahagún (siglos IX y X), León, 1976.

77 Los pueblos de Meruelo y Guemes se encuentran en el término de Hazas de Cesto y están respectivamente a unos cinco y quince kilómetros de la villa hoy llamada Hazas (p. j. de Entrambasaguas). Así mismo podemos señalar que en este documento se destaca la existencia de "fazas" en la zona donde hoy se encuentran los pueblos Hazas de Soba (p. j. de Ramales) y Hazas (p. j. de Laredo) y el Hazas (de Liendo).

78 Hemos corregido el texto editado por M. Serrano y Sanz, que escribe tierras y fazas con minúscula, a pesar haber dicho en la introducción (BRAH, 73, p. 420): "pongo mayúsculas como es debido". A nuestro entender, estos nombres en plural y seguidos de un "est" tienen forzosamente que ser representativos de formas toponímicas.

79 Este topónimo, hoy desaparecido, lo consigna Menéndez Pidal en Orígenes (\& 41.2 , p. 210). Para su localización se ha de tener presente que Solórzano es pueblo veci- 
a. 1047: et per illo tokornale usque ad illo termino de Sancti Romani, et uadit al illo bosso et ad illa pineta, et per illas faccas usque ad illo arroio [BRAH 73 (1918), doc. IX, 432].

a. 1085: donamus (...) in ipsa uilla quo uocitatur Solorceno, hereditatem nostra (...) et de alia parte pumare de Peretiello, carrera antiqua qui discurrit de Haças de Felguera, et alio pumare qui est a la Pedrosa [BRAH 74 (1919), doc. XXXIII, p. 29].

El examen de otros cartularios ha permitido corroborar que los mismos significados se registran en otras zonas y ha revelado que no todos los redactores de documentos notariales usaron faza en la misma medida, aunque desconocemos si ello fue debido a que en una determinada región no tuvo vitalidad o a que se consideró término demasiado vulgar para ser introducido en escritos en latín. Así vemos, por ejemplo, que frente a los diez testimonios (incluido un topónimo) del Cartulario de San Millán de la Cogolla ${ }^{80}$, obra que contiene el de fecha más antigua, en los documentos de Sahagún de los siglos IX y $\mathrm{x}^{81}$ y en los de Santa María de Piasca (857-1252) ${ }^{82}$ aparece un único ejemplo, del año 861 (editado en ambas colecciones), y que lo mismo sucede en las "Chartes" del Monasterio de Silos publicadas por Ferotín ${ }^{83}$ y en la colección diplomática de San Salvador de El Moral ${ }^{84}$. He aquí las citas donde se registran los mencionados testimonios:

a. 800: in loco que dicitur Agro maiore in campos de Taranco, de illa faza de Zeza usque ad semitario qui discurrit ad prato et (...) et usque ad illa Ripiella de agro Maurenti (S. Millán, doc. 2, p. 3).

a. 861: Vindemos vobis Argemundo et uxore tui Recoire terra in Piasca in loco ubi dicitur (...) et in illa faza super kasa mea porcione ad integritatem in aderato precio ipsas terras in duos modios (...) et tu dedis-

no de Hazas de Cesto, zona al norte de la cual aparece un Helgueras, y que existe un Helguero cerca de Hazas de Soba. Queremos destacar también que en este Cartulario sólo encontramos la grafía ıçı en nombres propios.

80 Serrano, L., Cartulario de San Millán de la Cogolla, Madrid, 1930.

81 Mínguez, José M. a , ob. cit. Queremos destacar que, cuando se habla de tierras, los nombres que aparecen en esta obra son muy distintos a los que se registran en el Cartulario de Santoña. Así vemos, por ejemplo, que en el de Sahagún se repiten los vocablos busto, pausata y corte, no localizados en el de Santoña; y que en este último se hace continua mención de 'felgarios', voz no consignada en el primero.

82 Montenegro Valentín, J., Colección diplomática de Santa María de Piasca, Santander, Diputación regional de Cantabria, 1991.

83 Ferotin, M., Recueil des chartes de l'abbaye de Silos, París, 1897.

84 Serrano, L., Colección diplomática de San Salvador de El Moral, en Fuentes para la historia de Castilla, vol. I, Valladolid, 1906. 
te nobis pro ipsas terras precium qui nobis placuit (J. M. ${ }^{a}$ Mínguez, op. cit., doc. 2, p. 24; J. Montenegro, op. cit., doc. 3, p. 33).

a. 949: in Ripaluenga tres fazas (...) et una faza deorsum calzata de Mirone et agrum de Dolquit latus villa (...) et in Savareggo una faza (S. Millán, doc. 46, p. 56).

a. 956: alias duas fazas sub Quoba (...) alia terra in Pozo latus de Monnio Blascoz; alias duas fazas in Villavizana latus Sarrazini Ovecoz; alium agro... (ibid., doc. 50, p. 61).

a. 1009: in Vallearmentero una faza travessania latus vinea de Monnio Simproni (ibid., doc. 74, adición, p. 83).

a. 1049: una vinea in Vinaslongas in arroio de Fazas [¿Arroyo de Fazas?] (ibid., doc. 140, p. 151).

a. 1058: offero et perpetualiter confirmo ad atrium sanctissimi Emiliani (...) et una faza qui dicitur de Torre (ibid., doc. 159, p. 170)

a. 1065: Ego Egga bita Moriellez (...) dono ad S. Emiliani (...) et tres fazas de vineas et uno malleolo in valle bellako (ibid., doc. 185, p. 193).

a. 1222: De linares: en el Gredal un linar, unde sunt alletanei Rudericus (...). Alius en el Lagremal, unde sunt alletanei Petrus Petri (...). Alia faza est in orto que fuit de palatio, unde sunt alletanei abbatissa et don Bela (Ferotín, Chartes del M. de Silos, p. 156) ${ }^{85}$.

a. 1279: tres heredades y seis faças de viña sitas a orillas del Arlanza (Cartulario del monasterio de El Moral) ${ }^{86}$.

Los sentidos aquí señalados son también los que se captan en los Documentos lingüísticos publicados por Menéndez Pidal, donde hemos localizado veintitrés testimonios ${ }^{87}$, dieciocho de faza y cinco de faça ${ }^{88}$, habiendo de destacar que esta obra (al igual que sucede con los Cartularios que han sido objeto de estudio) no contiene ejemplo alguno de voces como fasca, faisa o faxa que pudieran considerarse descendientes del latín FASciA. En lo que respecta al sustantivo faza/faça, éste se registra en documentos de zonas muy específicas. A excepción de uno de Sigüenza (Guadalajara) los restantes aparecen bien en la región de

\footnotetext{
85 En este documento, que trata de las tierras vendidas por Ordoño de Castillo Sarracin, se enumeran por separados las "tierras", "viñas" y "linares", lo que lleva a interpretar faza como 'campo de lino'.

86 El editor interpreta este testimonio por 'medida agraria' (cfr. ob. cit., p. 121 y nota 1)

87 No incluimos en esta cifra los correspondientes al Cartulario de Santoña, de los que hemos hablado con anterioridad.

88 No contabilizamos un testimonio del topónimo burgalés Aça (p. 253), hoy Hazas, de un documento del año 1261, cuya lectura revela que ha asumido la acepción de 'distrito' propia del étimo, al señalarse en él que los pueblos del término "pagaban portazgo en Aça".
} 
Aranda de Duero, bien al norte de Burgos, en el territorio que se extiende entre el nacimiento del río Pisuerga y el del río Ebro.

Dado que su análisis no aporta nada nuevo a nuestro estudio, nos limitaremos a señalar su contenido de manera abreviada: en un documento de Oña, de 1127, se menciona "alia terra (...) et alia faça so el Pennueco ${ }^{89}$; en otro, también de Oña, de 1202, se alude a "una faza de Elvira Oriolo, en medio desta viñas» ${ }^{90}$. En uno de La Vid (Aranda de Duero) de 1212, faza se repite ocho veces alternando con tierra: "otra faza carrera de Olmedillo (...) otra tierra carrera de Rodan; otra tierra entramos los arroios (...); otra faza cerca de la carrera de arroion; «en el prado a una faza»; «una faza que ha i Golzalvo Pérez»; «tres fazas, la una de don Ferrando....; "otra faza de la fuent, carrera de Baffardiela con su viña e con toda la tierran, etc. ${ }^{91}$. En uno de Gumiel de Izán (Aranda de Duero) de 1219, leemos: «una faça entre don Gómez e don Munio»; "una faça so la cozina de don Eluira" y "una faça de vinea a los Olmos» ${ }^{92}$. En dos de Aguilar de Campóo de 1220 y 1222 se señalan numerosas fazas como sinónimos de tierras, entre ellas, "la faza del Sotiello" y "duas fazas a la vinea» ${ }^{93}$; en el de fecha más tardía, de 1278, perteneciente al monasterio de Frías y donde se menciona el término "pedaço" junto al de "tierras", se habla de "otro pedaço en cabo de la villa (...) et otra faça». Finalmente, en el de Sigüenza (Guadalajara), de 1254 , se señala la venta de dos fazas de cuatro aranzadas en la sierra de Borialcayat (¿Burŷal qā’id?) ${ }^{94}$, fazas, las últimas, de tierra labrantía.

En resumen, el estudio de documentos pertenecientes a la llamada Castilla la Vieja pone de manifiesto que faza encerró en un principio el sentido de 'campo' o 'tierra', aplicándose a superficies donde se daban cultivos muy diversos y que fue, a partir del siglo xill cuando empezó a concebirse como 'tierra labrantía'. En lo que respecta al desarrollo del último significado, pensamos que resulta fácil de explicar. Si hemos visto que mediante faza se hacía referencia a terrenos con árboles frutales, viñas o cereales y también a campos de lino, se ha de suponer que cuando su uso se generalizó en Castilla, donde las tierras que más abundan son las llamadas «tierras de pan llevar», el primitivo faza 'cam-

89 Menéndez Pidal, R., Documentos lingüiśticos, p. 66.

90 Ibid., p. 69.

91 Ibid., 269-271.

92 Ibid., 275.

93 Ibid., 49-50. El de 1220 contiene ocho testimonios; el de 1222, uno.

94 Ibid., 345. 
po' pasó entonces a identificarse con campos donde se cultivaban cereales. Y ello hizo que terminase por asumir como principal significado ese "tierra labrantía" que recogen los diccionarios.

El uso de faza puede también observarse en territorio mozárabe, según comprobamos por dos documentos toledanos. En uno de ellos, de $1290{ }^{95}$, que trata de la venta de cincuenta y cinco "tierras», al indicarse el emplazamiento de la número catorce, la llamada "tierra grande», se dice que «linda con la de Albalate, con la Lonquera de Fernando Guteriz, con la tierra de la sobrina de Gonzalbo Esteban, y con la faza (ár. făsa) citada", faza que no es otra que la "tierra» (arḍ) número trece. En el segundo, donde se concreta el intercambio de tierras entre García Martínez y López Petrez, el árabe fāṣa se repetirá diez veces y vendrá a designar una serie de hazas de alcacel, es decir, porciones de tierra sembradas de cebada verde ${ }^{96}$. He aquí la traducción que hemos hecho del fragmento donde aparecen dichos testimonios y en el que encontramos ard 'tierra' como equivalente de faza.

García Martínez cede en función de intercambio (...) y toda la faza que produce alcacel ( $\hat{y} a m \bar{l}^{\prime}$ al-fäșa li-qașìl) y la heredad que tiene pro indiviso en dicha alquería (...). La mencionada faza de alcacel (fäsa-l-qașil) linda con la huerta (almunya) de Martín González (...) y con la faza de alcacel (bi-fäșa-l-qașill) del alguacil, ya que a él pertenece una parte de esta misma faza (hāḍa-l-fāṣa)...

López Petrez y sus hermanos dan a cambio (...) toda su faza que produce alcacel ( $\hat{y} a a_{i}{ }^{\prime}$ al-fäsa li-qașì), y que se encuentra detrás del mencionado corral (...). Esta faza (häda-l-fäsạa) limita con una segunda faza (bifäșa țāniya) de la que una parte es de los hijos de García Martínez. [También dan] toda la mitad que ellos tienen de la faza de alcacel (min făsa li-qașil) situada en la vega y que era del mencionado Alfonso Petrez; y toda la faza de alcacel (fäșa li-qașil) de su propiedad y que se encuentra contigua a la tierra que produce alcacel (bi-aṛd li-qässil) de los hijos de García Martínez y a la faza que produce alcacel (bi-fäsa li-qāsịi) de López Petrez y sus hermanos.

\subsection{Otros significados: ¿'porción', 'medida agraria'?}

No desechamos la posibilidad de que en determinadas regiones y en época tardía haza asumiera nuevos valores significativos, pero tam-

95 González Palencia, A., ob. cit., II, p. 316.22 (doc. 702).

96 Ibid., vol. III, p. 105 (doc. 824). 
bién creemos que éstos sólo podrán entenderse a partir de su sentido originario. Al igual que José M. Fórneas, pensamos que haza en Granada se empleó como equivalente a suerte, en su acepción décima de 'parte de tierra de labor' (DrAE), pero de la misma forma estimamos que no debe considerarse sinónimo de pedazo en el momento en que haza se aplica únicamente a tierras. La lectura de cartularios como el de Santa María de Fitero ${ }^{97}$, donde el vocablo peza se usa con frecuencia, en sustitución de tierra, pone de manifiesto que en algunas regiones se utilizaron vocablos como pieza o pedazo para designar 'pedazo de tierra', y nos lleva a pensar que lo mismo pudo suceder con haza, aunque sean voces con un campo semántico distinto, ya que no es posible hablar, por ejemplo, de hazas de pescado o carne.

He aquí algunas frases que trae J. M. ${ }^{a}$ Fórneas para documentar el significado de 'porción' y a las que sumamos otras de Mármol ${ }^{98}$, con el propósito de mostrar que haza en Granada también alterna con 'sembrado' y que nuestro vocablo siempre puede ser sustituido por campo o tierra, pero no por pedazo o porción.

Lo que está vacante de haças e olivos e almendros [Repartimiento de Comares (1487-1496) apudJ. M. ${ }^{a}$ Fórneas, art. cit., p. 121].

Otra haça de tres celemines de sembradura... (ibid.). (ibid.).

Otra haça de Mahomad Abençaat en el río del Borje con almendros

Dos pedaços de tierra en Cibares en que abra hasta dos cadaes de senbradura (ibid.).

Otro pedaço de haça de Hamed Abuciba que cabe hasta dos almudes de senbradura (ibid., p. 122)...

Con el agua de la fuente de Alfacar, que recogen los moradores en una acequia (...) se riegan las huertas y hazas de Alfacar, Baznar y Mora, y buena parte de viñas de la Vega (Mármol ob. cit., p. 134).

Aguas de fuentes y de ríos con que los campos, huertas y sembrados (Ibid., p. 135).

Que sus altezas hacen merced a la reina Ayxa y (...) de todas las huertas, hazas, molinos y viñas y otros heredamientos que tenían (ibid., p. 146).

Porque los enemigos de Dios araron de dos o tres rejas las hazas que estaban al derredor del lugar; $\mathrm{y}$ echando toda el agua de las acequias por ellas, empantanaron el campo (ibid., p. 156b).

97 Monterde, C., Colección diplomática del monasterio de Santa María de Fitero, Zaragoza, 1978 .

98 Mármol Carvajal, L. del, Historia del Rebelión y Castigo de los Moriscos del Reyno de Granada, en BAE, 21, Madrid, 1946. 
Finalmente, y en lo que se refiere al sentido de 'medida agraria', no creemos que pueda considerarse propio del haza castellano, aunque aceptamos la posibilidad de que haza se emplease con dicho valor en aquellas regiones y épocas en que las parcelas de tierra de sembradura se asociaban con una extensión determinada. Tal y como hemos señalado con anterioridad, ese significado sólo lo percibimos en un documento toledano de finales del xiII, lo que consideramos muy sintomático, ya que pertenece a una zona donde se utilizan vocablos árabes (como hawd) para designar indistintamente una parcela de tierra o una medida agraria.

Asimismo juzgamos que no debe atribuirse dicho significado, como lo hace Menéndez Pidal, a textos donde se mencionan, por ejemplo, "ocho fazas", porque entonces también debería aplicarse a campo o tie$r r a$, al ser frecuente que en los cartularios se hable de dos, tres, etc., tierras o campos. Por idénticos motivos pensamos que esta acepción no es la propia de la mayor parte de las citas que aportan los lingüistas para probar que el mismo significado lo asumieron formas derivadas del latín FASCIA y que se registran en expresiones como las que hemos copiado de Du Cange.

\section{3. «Haza» en textos literarios (siglos $X I V-X X)$}

Haza es palabra con una larga historia, no sólo notarial sino también literaria, aunque en este segundo caso su vida parece comenzar en el siglo xIv, época en que la usa el Arcipreste. En el xv, se encuentra en la Crónica de Lucas de Iranzo. En los siglos XVI-XVII, se ve frecuentemente en Juan Rufo, en Góngora, en Lope de Vega, en Quevedo, en Fray Hortensio de Paravicino y en escritores granadinos como Mármol. En tiempos modernos se puede señalar en Jovellanos y luego en novelistas como Valera o Galdós.

Se trata, pues, de una voz siempre en uso literario, si bien en los últimos tiempos su presencia en los textos ya no es tan frecuente, como no sea en escritores regionales. Sabemos que hoy día sigue muy viva en el campo andaluz y en algunas regiones castellanas, sobre todo en zonas campesinas, aunque también es cierto que haza va cayendo en desuso y ha dejado de ser inteligible para casi la totalidad de quienes hablan en castellano.

He aquí citas tomadas de textos literarios, cuya lectura revela que 
haza, además de designar 'porción de tierra labrantía', trasluce otros significados y que, en algunos contextos, parece conservar su sentido originario de 'campo'.

Travando con sus dientes descúbrese la çarça: /Echanla de la huerta, de vyñas é de haça (J. Ruiz, Libro de Buen Amor, v. 569 b).

Todas las collaciones y aldeas, cada una por si, vinieron y se pusieron por aquellas azas y eras (L. de Iranzo, Crónica, en Memorial histórico español VIII, p. 145).

Hermosa es una haza de pan, assi ahora en berza, con aquel verdor desigual, en que casi tropiezan unas con otras las cañas. (Hortensio Paravicino, Marial y Santorial, apud Autoridades).

Vi yo en algunos valles en el Mayz: que en una haça lo sembraban, y en otra estaba ya nascido (Garcilaso de la Vega, El Inca, Comentarios reales, ed. 1609, f. 250 v., según nota J. Oliver Asín).

Cejo llaman en España a la linde de una haça o heredad (Diego de Guadix, Vocabulario, año 1593, según nota J. Oliver Asín).

La población destos varrios es grandísima, con muchas calles de bizarras casas (...) como son La del Lavadero (...) La haza de los cardos, porque antiguamente lo era y salían las damas a comerlos en ella ( $\mathrm{F}$. Henríquez de Jorquera, Anales de Granada, Granada, 1934, I, p. 30).

Cuyo mi pobre padre tuvo a renta, / Ciertas estrechas hazas que sembraba (Hern. Eneid. lib. 12, apud Autoridades).

Anduvo aquel día cinco leguas por los montes, casi siempre a gatas; salió a unas hazas y halló tres mujeres en una casilla (F. López de Gomara, Conquista de Méjico, BAE, XXII, 417, 4).

Como de fuscos tordos a la haza / Acudir suele multitud crecida, / Cuando las rojas mieses embaraza, / Hallando sin defensa la comida (J. de Castellanos, Varones ilustres de Indias, BAE IV, 470, 2, 9).

Las rústicas cuadrillas de la siega / Con más presteza cortan los despojos / A las hazas que vuelven en rastrojo (J. Rufo, La Austríada, BAE XXIX, 30, 2.4)

Tanto llora el hi de puta, / Que si el año de la seca / Llorara en dos hazas mías / Acudiera a diez hanegas (Góngora, Romances, BAE XXXII, 529, 1, 15).

Ver mis segadores gusto, / Pues llego a buena ocasión / Que la haza cae aquí. (Lope de Vega, Peribáñez y el Comen., en BAE XLI, 293, 1, 64).

Este artículo de la fe católica no le enseñan en las hazas los gañanes (Quevedo, Cuna y vida, BAE, XLVIII, 97, 2, 3).

Andaba a caza de gangas / Y grillos vine a cazar, / Que en mi cantan como en haza / Las noches de por San Juan (...) A la encarcelada noche / llenan las hazas de grillos (ibid. El Parnaso español, BAE LXIX, 98, 1.4 (...) $179,1.50$ ).

¿Qué gusto hay cual madrugar / Con la misma aurora, a dar / A su luz la bienvenida, / Y de la simple comida / El tosco almuerzo aprestar, 
/ Porque vaya ver su haza (Tirso de Molina, No le arriendo la ganancia, BAE, LVIII, 271, 1.48).

[Tomo una yegua, dos perros y una escopeta] $\mathrm{Y}$ dando vuelta a mis hazas, / Viñas, huertas y heredades, / Corro y mato en su campaña / Un par de liebres... (J. de Martos Fragoso, Villano en su rincón, BAE XLVII, 209, 3.15).

Y ¿cómo había de llover en la haza del bueno, y no en la del malo, si están juntas? (F. Hernando de Zárate, Discursos de la paciencia cristiana, BAE XXVII, 620, 1.52).

Pregunta por sus hazas y cortijos (Francisco Gregorio de Salas, De Jaraicejo, Extram., BAE, LXVII, 525, 1, 48).

Yo no sé por qué no se les había de prohibir [a los que hacen ruido con sus arados y carretas] que alborotasen tan de madrugada, sino que acudiesen a la haza de nueve a doce, como se acostumbra en las más de las oficinas (Cartas del Doctor don Sebastian de Miñano y Berdoya, en ibid. LXII, 626, 1.43).

Oh, cuál me quedo absorta / al ver en hazas yermas, / con el calor fecundas cómo la mies prospera. (...) No esquilmeis el fruto de haza u olivar [J. Lorenzo Villanueva, BAE, LXVI, 589, 3.4 (...) 599, 2.13].

Divide las tierras en pequeñas porciones, las subdivide en prados, hazas y huertas (G. M. de Jovellanos, Informe sobre la ley agraria, BAE de Rivard. Obras de Jovellanos, t. 2, p. 89, según nota J. Oliver Asín).

Las hazas del ruedo y demás tierras de pan llevar estaban ya segadas, y sobre la negrura de la tierra amarilleaba el rastrojo, los cardos y toda la hierba seca, que el polvo y ardores de la canícula habían hecho como yesca [Juan Valera, Las ilusiones del doctor Faustino, en "Clásicos Castalia», núm. 26 (1970), p. 63].

Poseía José Caminero, por herencia, la casa en que vivía, dos huertas y hermoso prado, dos o tres hazas de excelente tierre, en que cosechaba patatas, trigo para el pan de la casa, garbanzos, algarroba [B. Pérez Galdós, El caballero encantado, ed. Cátedra, núm. 54 (1979), p. 120].

En suma, el análisis de documentos notariales de la vieja Castilla y de textos literarios pone de manifiesto que haza nace en nuestro suelo en época muy temprana y es palabra que, por usarse en un principio como equivalente a campo o tierra y traslucir más tarde acepciones relacionadas con dichos valores, no ha podido derivar de una FAISA latino, que se documenta en el xv, y que significó 'banda o cinta'.

\section{El árabe FAḤS}

La palabra árabe FAHS coincide fonética y semánticamente con el castellano haza y es término que aparece registrado en los antiguos vo- 
cabularios hispanoárabes con las mismas acepciones que hemos dicho corresponden al actual haza.

El principal significado de FAHS, el de 'campo' o 'campiña', se consigna en todos los diccionarios de uso común, y ya en el siglo XIII vemos al Vocabulista traducir FAH̦S, por el latín 'campus' (pl 153). Más importante nos parece destacar que el sentido que trae de haza el DRAE fue también característico del árabe occidental. En el siglo XVI P. de Alcalá interpreta FAḤ como 'campo que se labra' (p. 137.3); mucho antes, el famoso geógrafo Yāqūt (h. 1179-1229) nos ofrece, en su conocida obra $M u$ ŷam al-buldān, un interesantísimo pasaje revelador de que las acepciones actuales del español haza se consideraban particulares del árabe que se habló en la Península. Este gran escritor oriental había leído con frecuencia la palabra FAHS en libros andalusíes, pero no entendía exactamente su significación. Por ello, al toparse con un habitante de al-Andalus, inmediatamente le preguntó qué es lo que en su región se entendía por fahs y reprodujo su respuesta: «Todo lugar que se habite, lo mismo si está en llano que en monte, con tal que se siembre, le llamamos en al-Andalus fahṣ». Así lo narra el propio Yāqūt, tras señalar que son muchos los territorios conocidos en España por este nombre ${ }^{99}$.

El mismo sentido lo encontramos en la obra de agricultura de Ibn al-'Awwām ${ }^{100}$. Dicho autor, al hablar de la tierra en cuya superficie aparecen grietas, es decir, de la arcillosa, va a detenerse para precisar que no comparte la opinión negativa que de ella tenían Demócrito y Abū 'Umar Ibn Haŷŷâŷ. Y lo hará mediante un breve párrafo en el que utiliza el vocablo FAHS como definitorio de campos en los que se cultiva trigo. He aquí la traducción de sus palabras:

Mas nosotros vemos que la tierra labrantía de la ciudad de Carmona (fahs madinat Qarmüna) es muy agrietada y que, sin embargo, de ella se sacan cosechas de trigo más copiosas que de otras que no lo son. Por lo tanto mi opinión es que no debe desecharse ese tipo de tierra.

El significado que se capta en los documentos castellanos más antiguos coincide, por lo tanto, con el que ha de considerarse principal y originario del étimo, mientras que ése de 'tierra labrantía', que trae el

99 Jacut's Geographisches Worterbuch, ed. Wünstenfeld, Leipzig, 1868, t. III, p. 852.

100 Ibn al-'Awwām, Libro de Agricultura, ed. facsímil de la obra de Banqueri (Madrid, 1802), 2 vols., Minist. de Agricultura, Madrid, 1988, I, p. 42. 
DRAE como primera definición de haza es un matiz que también adopta el FAḤs árabe en occidente y en particular, en al-Andalus.

Un FAHS, al igual que un haza, no es un campo estrecho y alargado puesto que sobre la forma de su perímetro nada advierten los geógrafos y agrónomos árabes; un FAHS tiene que ser un terreno que permita, por su suficiente amplitud, la habitabilidad; un FAHS puede estar sobre un llano o sobre el monte con tal de que no sea una tierra yerma, pues característica esencial no es la forma sino la condición de tierra laborable. Su sentido coincide, pues, con el de haza: campo de contorno indefinido; habitable; sobre la llanura o en donde lo permite la montaña y, sobre todo, de tierra de sembradura.

Importante es también recordar que FAHs es vocablo que, debido a su significación, se usa con frecuencia como topónimo ${ }^{101}$, y que derivados románicos de FASCIA no pasan de nombre común a nombre propio de población, al igual que sucede con bancal, aunque pueda existir, eso sí, algún nombre geográfico, como el citado de Les Faisses, cuya función será definir simples terrenos caracterizados por sus fajas o bancales. Los topónimos derivados de FASCIA, por aplicarse a tierras angostas o estrechas, sobre las que es imposible se forme núcleo de población alguna tienen que ser muy raros; no sucede lo mismo con fahs, haza y campo, voces con capacidad para dar nombre a una tierra en que radiquen sus cultivadores y formen poblado. La consulta de diccionarios geográficos árabes e hispanos viene en apoyo de nuestras afirmaciones al dar a conocer la existencia de muchos lugares denominados Fahs o Campo y Haza, y apenas contener voces que designen 'faja' o 'bancal'.

\section{Paso del árabe FAḤS al romance haza}

En el plano fonético no existe impedimento alguno para defender la conversión del FAHS árabe en el haza romance, desarrollo que ha de considerarse normal. En primer lugar, de todos es conocido que la if inicial árabe se ha conservado en determinadas regiones y que es característico del castellano su transformación en 'h y y su posterior desaparición, cambio que se documenta en un alto número de arabismos. Se-

101 Para documentar esta afirmación no tenemos más que recorrer los índices de obras históricas y geográficas árabes. 
gundo, sabemos que son muchas las palabras que contienen una $\backslash \mathrm{Z}$ ı (o la grafía antigua 'çı) como resultado de un șād ${ }^{102}$; que los mozárabes toledanos transcribieron nuestra haza por el árabe fāsa, es decir, emplearon la misma /s/ que contiene el étimo, y que incluso existe algún ejemplo aislado de /s / dando ixı y luego ij, lo que explicaría la presencia del sonido /š/ en algún derivado ${ }^{103}$. Tercero, la aparición de la ıa final no puede extrañar, cuando se conoce que los términos hispanos nacidos de otros árabes terminados en consonante toman una vocal de apoyo.

Todo esto supone que si FAHṢ sigue un proceso normal se ha de esperar, para el nombre común: faze, faza, haze, haza, aza, y, excepcionalmente, faxa, faja. Asimismos hemos de considerar natural que en los topónimos compuestos en los que FAHS aparece como primer elemento y seguido del artículo al- o de una palabra que comienza con vocal, los resultados sean $f a z-$, haz-, az-

Para la documentación de dicho desarrollo fonético contamos, además, con un alto número de topónimos y con una curiosa expresión, cuyo análisis revela que el árabe FAḤs se pronunció /ha日/ en latín y romance. Nos referimos al vocablo compuesto fahs al-damm 'campo de la sangre' transcrito en latín por Haceldama, y que, como voz hispana, es registrada también en nuestros diccionarios 104.

En lo que respecta a los nombres geográficos, sobre los que hablaremos en un futuro artículo, podemos adelantar que serán examinadas formas como Fazálvaro / Haçalvaro / Azalvaro; Moratalfaz / Moratalaz; Fazali, Façalcazar, Fazouro, Azcamellas, Acellana, etc., y que incluso contamos con determinados topónimos que, por registrarse en documentos árabes y romances, son prueba evidente de la existencia de la forma medieval haç-a como derivada de FAHȘ. Este es el caso, por ejemplo, de Fahș al-Maŷrițt, que en el siglo xv era Haça-l-Madrid, o de Fahs al-Qaṣr, que en un documento de Alfonso X es Façalcazar.

102 Como ejemplo podemos citar los muchos vocablos nacidos de un șähib (zabazoque, zalmedina, zabasorta, zabazala) o de un hiṣn (Aznar, Aznalcázar, Aznalfarache, Aznarón, Iznájar, Iznatoraf).

103 Sobre este cambio véase Corriente, F., Sketch..., p. 50, 2.17.1, y González Palencia, A., "Documentos árabes de Cenete» (Al-Andalus V, p. 306), donde se señala un Faḥs al-Hawza, hoy Fajalauza.

104 Sobre la transcripción latina véase el texto de Aldrete que reproducimos bajo el siguiente epígrafe. Para la documentación de la expresión romance, véase Esteban de Terreros y Pando, Diccionario castellano con las voces de ciencias y artes (1787), Madrid, 1987, p. 257. 


\section{Antecedentes de esta etimología y últimas observaciones}

Antes de terminar este artículo queremos señalar que la etimología aquí defendida tiene ya antecedentes estudiados por Jaime Oliver Asín, como puede constatarse por unas notas suyas que a continuación reproducimos.

«Hace más de tres siglos, le señaló el mismo origen el famoso Aldrete 105 cuando en una de sus conocidas obras se puso a atacar a los hebraístas que se empeñaban en ver a cada paso voces hebreas dentro del castellano. Una de ellas era haza sobre la que leemos lo siguiente:

"De donde vinieron las dicciones hebreas que [dicen] hay en nuestra lengua? De la hebrea no porque nadie la ha hablado en España, de suerte que della se hubiesen podido pegar y recibir. De la árabe sí; y tanto quanto, con gran daño, todos sabemos. Júntense pues todas las dicciones que se reputan por hebreas, y se hallará que los que son bien entendidos en la arabía, afirmarán que son della y todas unas con las que se saben y conocen por árabes. Una della es Haça. Y luego traen el exemplo del Sancto Evangelio: Propter hoc vocatus est ager ille Haceldama, hoc este ager sanguinis, que el Syro dixo Hakaldamò y el hebreo en la lengua santa dizia שדה al campo y הרס a la sangre y así Sçadeh hadam.

Ni del uno ni del otro [ni del sirio ni del hebreo] se adoptó en el lenguaje vulgar el nombre de haça, sino del Arabe, que le llamó fahç, y dél se dixo faça y después haça, trocando la $f$ en aspiración conforme se suele, i e dicho. Confirmase esto más, que no a muchos años que se recibió en uso no hallándose en la leies de las Partidas ni historias antiguas ni en los diccionarios de cien años atrás.»

"No creo que Aldrete haya sentado esta etimología sin informarse antes de algún morisco bilingüe, que es lo que hacían los eruditos de aquel tiempo. El mismo confiesa que sostuvo relación con un marroquí (morisco como eran todos los buenos funcionarios de la corte sa'dī) que vino a España acompañado de Muley Xeque, el hijo de Aḥmad alManșūr. Bien pudo, pues, ser él quien le informara. De todas maneras, un morisco culto tenía que ser quien viera perfectamente la relación entre haza y fahs. Un morisco cuyo testimonio -por ser propio de quien conoce el árabe vulgar hispánico de los últimos momentos, a la vez que

105 Bernardo Aldrete, Varias antigüedades de España, Africa y otras provincias, Amberes, 1614, p. 263, s.n. Oliver Asín. 
la lengua castellana - tiene, por fuerza, que tener para nosotros un gran valor."

La etimología de Aldrete no pasó inadvertida para el gran filólogo colombiano Rufino José Cuervo, quien la recogió y dio como buena en una nota de sus Disquisiciones sobre antigua ortografía y pronunciación castellanas, al incluir, sin más, la palabra haza entre aquellas árabes cuyo șâd original aparece en castellano como içı.

Nadie, al parecer, ha prestado la debida atención a la nota de Cuervo. Si alguien se ha fijado en ella, es indudable que le ha parecido tan arbitraria como para no hacer siquiera una mención de la misma. Tal actitud se comprende, sobre todo si se ha recurrido en busca de su comprobación al Glosario de Dozy y Engelman, donde nada se dice de haza, o al de Eguilaz, quien, si la cita, es para señalar que viene del latín FASCIA conforme a la etimología que había dado Díez.»

Yo estoy convencida de que Aldrete y Cuervo no se equivocaron y que Jaime Oliver Asín no habría tenido problemas para defender su misma tesis si los romanistas no hubiesen tratado de sentar las bases de una nueva etimología a lo largo de más de un siglo. J. Oliver intuyó que nuestro haza sólo podía venir del árabe FAḤs e intentó demostrarlo, pero pronto se sintió desbordado, precisamente porque no se dio cuenta de la imposibilidad de ofrecer una teoría convincente si para fundamentarla partía de todas esas frases que, conteniendo testimonio de ha$z a$ o faxa, repiten los lingüistas en sus trabajos.

Yo también he de confesar que, tras reunir las notas de Jaime Oliver y consultar las obras a las que aludía, estuve a punto de darme por vencida, debido sobre todo a que me resultaba muy difícil rechazar el étimo latino cuando escuchaba a los lingüistas y aceptaba como buenos los datos incompletos que en defensa de sus tesis iban aportando. Sus palabras parecían sugerir que faxa, faisa 'faja de tierra' se usaron con frecuencia en las diversas lenguas romances, y desde muy antiguo, y que el castellano faza o haza no era más que una variante de las anteriores cuyo sentido originario de 'faja' era indiscutible, al documentarse como propio de la expresión "faza de tierra».

Nuestras dudas sólo empezaron a disiparse cuando decidimos olvidarnos de lo que hasta ahora se había dicho y realizar un estudio sistemático de fuentes de la vieja Castilla, con la finalidad de conocer la fecha en la que se documentaban grafías y significados, y poder así reconstruir la historia de haza. Fue entonces cuando descubrimos que los testimonios localizados en documentos castellanos contenían los 
mismos sentidos que el árabe FAب̣s; que éstos aparecían bajo las formas faza, faça, o sus homófonas, no dándose ejemplo alguno de los fasca y faxa tan repetidos; que faza de tierra se usó en su origen como equivalente de agro de terra; y que los textos a los que los lingüistas remitían eran con frecuencia de fecha muy tardía y no parecían contener testimonios con los significados aducidos. Fue también entonces cuando comprendimos que no existía relación semántica alguna entre el faza castellano y los auténticos derivados de un latín FAsciA 'faja' y que el nacimiento del faza 'tierra labrantía', voz, no lo olvidemos, exclusiva del español podía fácilmente explicarse si se pensaba en el contenido sémico del FAHS árabe. Asimismo, nos dimos cuenta de que su adopción venía a llenar un vacío lingüístico, en el momento en que, frente a campo y tierra, vocablos recargados de significaciones múltiples, la nueva voz servía para diferenciar el simple 'campo labrantío'.

Es cierto que para conseguir nuestro propósito hemos tenido que recorrer un difícil camino e ir apartando las muchas barreras que los lingüistas habían levantado, al tratar de justificar el origen latino de una palabra cuya génesis no resultaba sencilla de explicar.

Esperamos que el esfuerzo que nos ha supuesto el tener que rebatir teorías y examinar un alto número de documentos notariales haya servido para demostrar que la tesis defendida por Jaime Oliver era la acertada, tesis que no dudamos saldrá reforzada cuando volvamos sobre ella en un próximo artículo, en el que daremos cuenta de los diferentes derivados de FAHS que aparecen en la toponimia y en el que se pondrá de manifiesto la existencia de nombres de lugar que, conteniendo haza y $a z a$, proceden de manera indiscutible del árabe fahs.

\section{RESUMEN}

En este artículo tratamos de demostrar que el término español haza procede del árabe FAHȘ 'campo' y no del latín FASCIA 'banda, tira', tesis admitida de manera unánime. Para conseguir nuestro propósito hemos reconstruido la historia de este vocablo a través del estudio de fuentes documentales y textos literarios. Como resultado de ello demostramos que $h a z a$, en su forma arcaica $f a-$ $z a$, aparece en Castilla en el siglo Ix; ponemos de manifiesto que en un principio asumió los significados del étimo árabe, para desarrollar más tarde nuevos sentidos y finalmente, explicamos la evolución fonética experimentada por fahs hasta convertirse en haza. 


\begin{abstract}
In this article we try to prove that the Spanish word haza comes from the Arabic FAHS and not from the Latin FASCIA 'strip' as is generally admitted. In order to do this we have reconstructed the history of this voice through the study of documentary sources and literary works. As a result, we establish that haza, written faza in early times, first appeared in Castile, in the ninth century; we show how, in the beginning, it adopted the same meanings as the Arabic root word, before developing other new ones; and we furthermore follow the phonetic evolution form fahṣ to haza.
\end{abstract}

